\title{
3-methylcrotonyl-CoA carboxylase deficiency
}

INSERM

\section{Source}

INSERM. (1999). Orphanet: an online rare disease and orphan drug data base. $\underline{3-}$ methylcrotonyl-COA carboxylase deficiency. ORPHA:6

3-methylcrotonyl-CoA carboxylase deficiency (3-MCCD) is an inherited disorder of leucine metabolism characterized by a highly variable clinical picture ranging from metabolic crisis in infancy to asymptomatic adults. 